\title{
Phylogeny and morphology of Glugea hertwigi from rainbow smelt Osmerus mordax found in Prince Edward Island, Canada
}

\author{
J. Lovy ${ }^{1, *}$, M. Kostka ${ }^{2}$, I. Dyková ${ }^{2}$, G. Arsenault ${ }^{3}$, H. Pecková ${ }^{2}$, G. M. Wright ${ }^{1}$, \\ D. J. Speare ${ }^{3}$ \\ ${ }^{1}$ Department of Biomedical Sciences, Atlantic Veterinary College, University of Prince Edward Island, 550 University Ave., \\ Charlottetown, Prince Edward Island C1A 4P3, Canada \\ ${ }^{2}$ Institute of Parasitology, Biology Centre, ASCR, Branišovská 31, 37005 České Budějovice, Czech Republic \\ ${ }^{3}$ Department of Pathology and Microbiology, Atlantic Veterinary College, University of Prince Edward Island, \\ 550 University Ave., Charlottetown, Prince Edward Island C1A 4P3, Canada
}

\begin{abstract}
Infection of rainbow smelt Osmerus mordax with the microsporidian Glugea hertwigi was diagnosed for the first time in Prince Edward Island, Canada. The prevalence of infection was $24 \%, 45$ infected out of 187 examined fish captured in February and March 2009. Both large and small xenomas of $G$. hertwigi observed within the submucosa of the gastrointestinal tract and along the mesentery of the host contained only mature spores. Advanced and degraded xenomas associated with host reaction were described using light and transmission electron microscopy. The first rDNA sequence of $G$. hertwigi prepared in the present study completed the set of sequences of Glugea spp. available for comparison. The high level of rDNA sequence identity between Glugea spp. suggests that these may be variants of a single species.
\end{abstract}

KEY WORDS: Glugea hertwigi $\cdot$ Microsporidia $\cdot$ Fish $\cdot$ Phylogeny $\cdot$ Morphology $\cdot$ Ultrastructure

\section{INTRODUCTION}

Rainbow smelt Osmerus mordax is an anadromous fish that supports a commercial and recreational fishery in Prince Edward Island (PEI), Canada. Currently there is very little data available on the health of these smelt. In April 2008, smelt were caught from a freshwater stream during their spawning migration and large parasitic cysts were observed within the gastrointestinal tract. Wet-mount preparations of the content of parasitic cysts demonstrated the presence of a microsporidian parasite, likely Glugea hertwigi Weissenberg, 1911. G. hertwigi is a microsporidian parasite reported in rainbow smelt throughout the Great Lakes and the Atlantic (Haley 1954, Chen \& Power 1972), although the parasite was previously unidentified in smelt populations in PEI. Severe infections with the parasite were thought to be associated with mortality of young-of-the-year smelt in the Great Lakes (Nepszy et al. 1978), adult smelt in Quebec (Delisle 1972), and European smelt $O$. eperlanus in Europe (Ieshko et al. 2000). Considering the disease implications that the parasite may have in both young-of-the-year and adult fish, it is of interest to document the prevalence of $G$. hertwigi and the health of the rainbow smelt populations in PEI.

Historically the classification of Glugea hertwigi was based on the identification of the microsporidian parasite in euryhaline smelt of the genus Osmerus and in pond smelt of the genera Hypomesus and Coregonus (Canning \& Lom 1986). The original description of the parasite was based on spore size, host species, and anatomical location. In addition to host and anatomical niches, a full characterization of microsporidian species is through morphological and molecular studies examining relatedness to other species. Although G. hert- 
wigi has been documented in smelt populations throughout Europe and the Atlantic, morphological and molecular data on the parasite are currently lacking. Microsporidia in the genus Glugea have been considered problematic; however, it has been demonstrated that $G$. anomala and $G$. stephani are likely the same species, whereas $G$. americanus belongs in fact to the genus Spraguea (Pomport-Castillon et al. 2000, Freeman et al. 2004). In the present study, G. hertwigi from $O$. mordax is characterized with transmission electron microscopy (TEM) and ribosomal DNA (rDNA) sequences to determine its relatedness within the genus Glugea.

\section{MATERIALS AND METHODS}

Prevalence data. During the spawning migration (in April 2008), rainbow smelt were captured with a dip net from a tributary of the North River, PEI. Approximately 120 predominantly male fish were captured and upon dissection, microsporidian xenomas were observed within the gastrointestinal tract in roughly $20 \%$ of the fish. The content of xenomas was examined in fresh fish samples to confirm the presence of microsporidian spores. Some xenomas were fixed in $70 \%$ ethanol and stored in a $-80^{\circ} \mathrm{C}$ freezer for molecular analysis, while other xenomas were fixed in $2 \%$ glutaraldehyde and processed for TEM.

In order to collect more accurate data on the prevalence of Glugea hertwigi infection in rainbow smelt, sampling was repeated in winter 2009 from Hillsborough River, PEI, on 3 sample dates (February 25, March 5 and 9). Smelt were captured through the ice with a spear and were either frozen for future examination or examined immediately after capture for the presence of xenomas. From a total of 187 fish, sex was noted, total length was recorded $(\mathrm{cm})$, and the presence or absence of infection was noted including observations on size of xenomas and intensity of infection. Upon visual inspection, the infections were designated as light, moderate, or heavy, indicating an infection with $<5$ xenomas, between 5 and 15 , or $>15$ respectively. Upon examination of fresh fish samples, any tissue that contained small xenomas was fixed in Karnovsky's fixative, comprised of $4 \%$ paraformaldehyde and $1 \%$ glutaraldehyde in phosphate buffer, for examination with microscopy.

Light and electron microscopy. Samples for routine light microscopy were dehydrated, infiltrated with xylene, and embedded in paraffin wax. Sections (5 $\mu \mathrm{m}$ thick) were cut, stained with hematoxylin and eosin (H\&E), and examined under a light microscope. For TEM, subsequent to fixation in Karnovsky's fixative for $24 \mathrm{~h}$ at $4^{\circ} \mathrm{C}$, samples were washed in phosphate buffer and postfixed in $1 \%$ osmium tetroxide for $1 \mathrm{~h}$ at room temperature. Samples were then washed in distilled water and dehydrated through a graded series of ethanols. The tissue was then submerged in propylene oxide and infiltrated in increasing ratios of Spurr's resin and propylene oxide (Canemco-Marivac). The samples were kept in pure resin overnight in a vacuum desiccator and finally embedded in pure fresh Spurr's resin. Semi-thin $(0.5 \mu \mathrm{m})$ sections were cut and stained with toluidine blue and examined with a light microscope. Ultra-thin (90 nm) sections were cut from areas of interest and examined and photographed with a Hitachi 7500 TEM operated at $80 \mathrm{kV}$. Determination of the number of polar filament coils in mature spores included counts of 10 spores that were cut along their long axis.

DNA extraction, PCR amplification, and sequencing. Spores collected from xenomas were transferred to double-distilled water and washed several times with repeated centrifugation at $4000 \times g$ for 2 min. DNA was extracted using the JETQUICK Tissue DNA Spin Kit (Genomed) after previous $0.5 \mathrm{~mm}$ glass-bead homogenization and disruption of spores using the FastPrep ${ }^{\circledR}-24$ Instrument (M.P. Biomedicals). The targeted DNA (partial small subunit [SSU] rDNA + internal transcribed spacer [ITS] + partial large subunit [LSU] rDNA) was amplified by PCR in 2 overlapping fragments with primer pairs 18F (5'-CAC CAG GTT GAT TCT GCC-3')-1492R (5'-GGT TAC CTT GTA CGA CTT-3') and 530F (5'-GTG CCA GC(C/A) GCC GCG G-3')-580R (5'-GGT CCG TGT TTC AAG ACG G-3') (Vossbrinck et al. 1993, 2004). PCR was carried out in a $25 \mu$ reaction volume using $10 \mathrm{pmol}$ of each primer, $250 \mu \mathrm{M}$ of each dNTP, $2.5 \mu \mathrm{l}$ of $10 \times$ Taq polymerase buffer, and 1 unit of TaqDNA polymerase (Top-Bio). The reactions were run on a Tpersonal Thermocycler (Biometra). The cycling conditions consisted of initial denaturation at $95^{\circ} \mathrm{C}$ ( $\left.5 \mathrm{~min}\right), 35$ cycles of denaturation at $94^{\circ} \mathrm{C}(1 \mathrm{~min})$, annealing at $50^{\circ} \mathrm{C}(30 \mathrm{~s})$, and extension at $72^{\circ} \mathrm{C}(2 \mathrm{~min})$ followed by a final extension at $72^{\circ} \mathrm{C}$ (10 min). The amplified products were purified from $1 \%$ agarose gel using JETQUICK Gel Extraction Spin Kit (Genomed) and cloned into pDrive Cloning Vector using the QIAGEN PCR Cloning Kit (Qiagen). Both strands were sequenced on an automatic sequencer ABI 3130x1 using the ABI PRISM BigDye Terminator v3.1 Cycle Sequencing Kit (Applied Biosystems) with M13 forward and M13 reverse primers.

Phylogenetic analysis. An alignment of 8 sequences deposited in GenBank as sequences of Glugea spp. together with the newly prepared sequence of G. hertwigi, 3 Loma spp. sequences, and 2 outgroups was prepared in ClustalX 2.0.6 (Larkin et al. 2007). The sequences were carefully examined for ambiguously aligned positions, which were deleted manually in BioEdit (Hall 1999). Four different methods were used 
to reconstruct the phylogenetic relationships among the included species. Maximum likelihood (ML) analyses were run in the program RAxML 7.0.3 (Stamatakis 2006). We used the GTR + gamma model and rapid bootstrapping option (100 replicates). Maximum parsimony (MP) trees and analyses employing the FitchMargoliash method with LogDet distances (LD) were computed in PAUP* 4.0b10 (Swofford 2001). Heuristic searches were conducted with 10 addition-sequence replicates in which the starting tree was constructed by random taxa addition and swapped with the truncated balanced realization (TBR) algorithm. The number of bootstrap replicates was 1000 for both MP and LD. The program MrBayes 3.1.2 (Ronquist \& Huelsenbeck 2003) was used to perform a Bayesian analysis (BA) of the dataset. Four simultaneous Markov Chain Monte Carlo (MCMC) chains were run for $10^{6}$ generations with sampling frequency 100 generations and burn-in 2500. The -ln L scores were plotted against the generation to determine appropriate burn-in. The percentage of identity among Glugea species sequences were calculated in the program MegAlign (DNASTAR). A shorter alignment consisting of $1169 \mathrm{bp}$ was used because only this part of rDNA sequence was available for the Glugea species under study.

\section{RESULTS}

\section{Prevalence}

The prevalence of Glugea hertwigi in the sampled fish was approximately $24 \%$ (45 infected/187 total fish). The mean lengths and sex of fish in relation to severity of infection are summarized in Table 1.
Table 1. Glugea hertwigi infecting Osmerus mordax. Prevalence of parasite in rainbow smelt sampled in February and March 2009 showing the relationship of the severity of infection to sex and mean length

\begin{tabular}{|lcccc|}
\hline $\begin{array}{l}\text { G. hertwigi } \\
\text { infection }\end{array}$ & $\begin{array}{c}\text { Prevalence } \\
\text { (n) }\end{array}$ & Male/Female & \multicolumn{2}{c|}{ Mean \pm SD length $(\mathrm{mm})$} \\
\hline Total fish & 187 & $106 / 81$ & $166.8 \pm 14.7$ & $174.2 \pm 16.4$ \\
Uninfected & 142 & $82 / 60$ & $167.9 \pm 15.8$ & $175.0 \pm 17.3$ \\
Infected & 45 & $24 / 21$ & $162.8 \pm 9.0$ & $172.0 \pm 9.0$ \\
Light & 21 & $9 / 12$ & $159.4 \pm 9.2$ & $172.7 \pm 7.9$ \\
Moderate & 15 & $10 / 5$ & $166.1 \pm 8.9$ & $178.0 \pm 22.8$ \\
Heavy & 9 & $5 / 4$ & $163.0 \pm 8.4$ & $162.5 \pm 5.0$ \\
\hline
\end{tabular}

\section{Morphology}

Variably sized xenomas, ranging from $<1$ to $4 \mathrm{~mm}$ of Glugea hertwigi, were observed in the submucosa of the gastrointestinal tract extending from the stomach to the posterior intestine and within the mesentery. Individual fish had uniformly small xenomas (Fig. 1A), uniformly large xenomas (Fig. 1B), or a mixture of large and small xenomas (Fig. 1C). Histological examination of
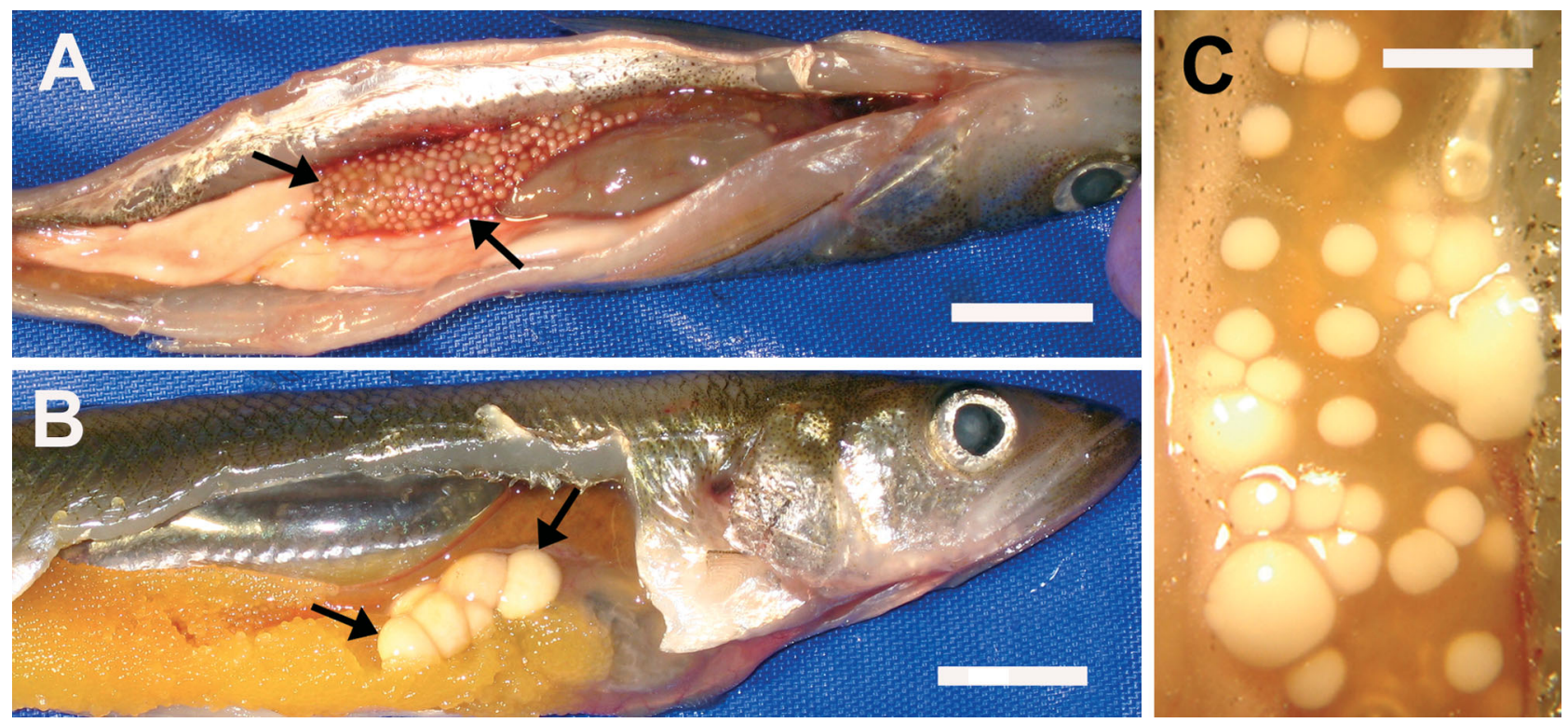

Fig. 1. Glugea hertwigi infecting Osmerus mordax. Variably sized xenomas in the gastrointestinal tract of infected rainbow smelt. (A) Heavily infected individual with uniformly small xenomas $(\rightarrow$ ) (scale bar $=1 \mathrm{~cm}$ ). (B) Moderate infection with uniformly large xenomas $(\rightarrow)$ (scale bar $=1 \mathrm{~cm})$. (C) Individual with a mixed infection of small and large xenomas $(\mathrm{scale}$ bar $=4 \mathrm{~mm})$ 
H\&E-stained sections demonstrated that xenomas of all sizes contained predominantly mature spores. Various stages of xenoma degeneration were also observed. Within a single sample were intact xenomas surrounded by highly eosinophilic walls (Fig. 2A,B), xenomas with an increased number of host cells surrounding the xenoma wall (Fig. 2C), xenomas which had lost their eosinophilic wall and contained a heavy influx of host cells (Fig. 2A), and degraded granulomas, which were likely remnants of broken-down xenomas (Fig. 2D). TEM confirmed that only mature spores and no developmental stages were present within xenomas. In addition, they contained degenerated and empty spores and infiltrated host inflammatory cells (Fig. 3A).

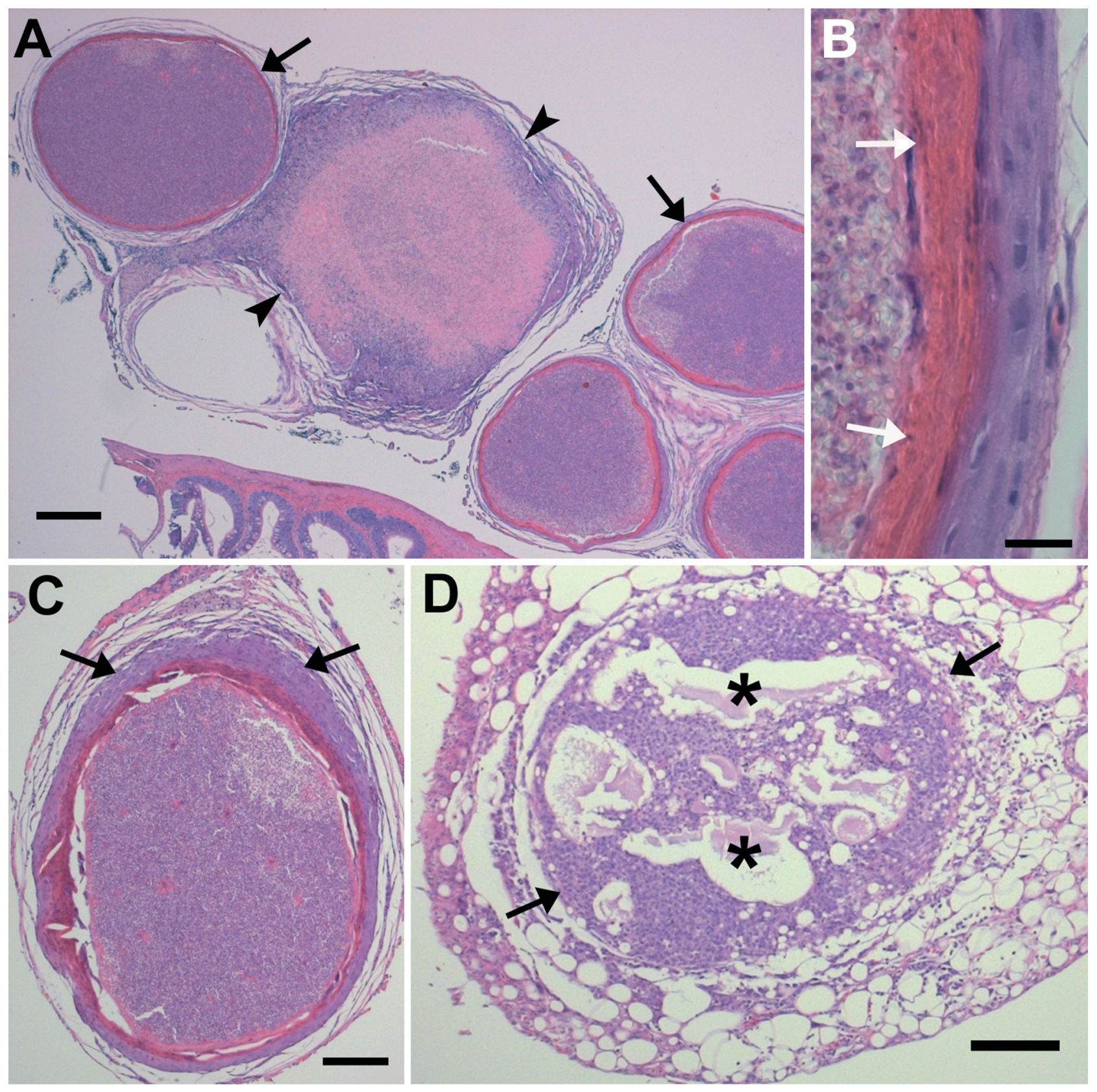

Fig. 2. Glugea hertwigi infecting Osmerus mordax. Various stages of xenoma degeneration in infected rainbow smelt. (A) Intact xenomas surrounded by highly eosinophilic walls $(\rightarrow)$ and a xenoma lacking the eosinophilic wall and containing a heavy infiltration of host cells and fibrin $(>)$ (scale bar $=200 \mu \mathrm{m}$ ). (B) Higher magnification of the xenoma wall, which consists of an eosinophilic layer composed of collagen $(\Leftrightarrow)$ ) and a thin surrounding of host cells (scale bar $=10 \mu m)$. (C) Xenoma surrounded by an increased number of host cells $(\rightarrow$ ) (scale bar $=100 \mu \mathrm{m}$ ). (D) Degraded xenoma $(\rightarrow)$ in the mesentary containing host cells and amorphous material $(*)$ (scale bar $=100 \mu \mathrm{m})$ 

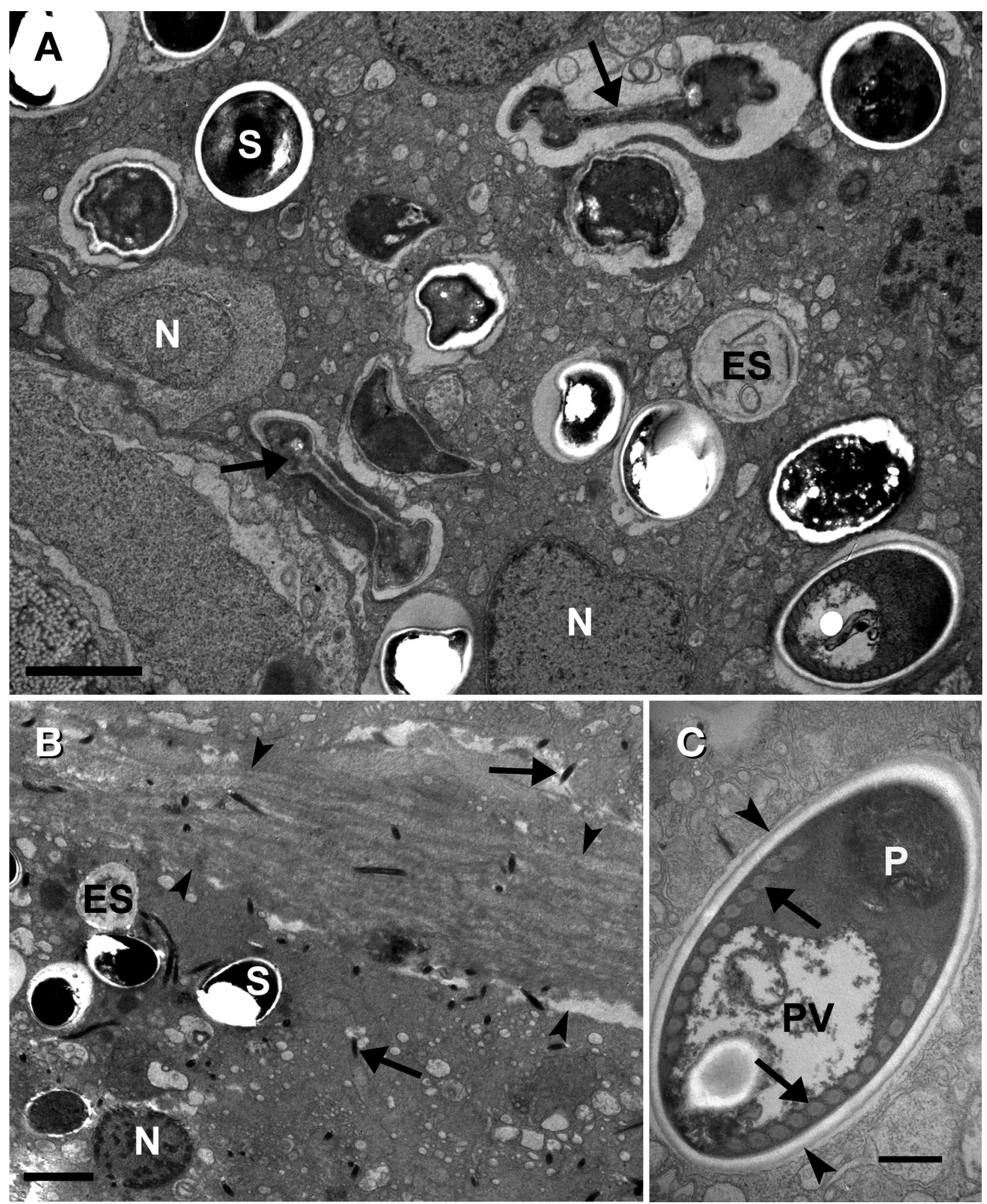

Fig. 3. Transmission electron micrographs of Glugea hertwigi. (A) Xenoma containing mature spores (S), empty spores (ES), degenerated spores $(\rightarrow)$, and host cells ( $\mathrm{N}=$ nucleus). Collagen, which makes up the xenoma wall, can be observed in the bottom left corner (scale bar $=2 \mu \mathrm{m}$ ). (B) Periphery of a xenoma with a defined collagenous wall ( $>$ ) containing mature spores (S), empty spores (ES), and numerous sections of the spore polar filament $(\rightarrow)$ within the xenoma, piercing the xenoma wall, and in the host tissue outside the xenoma (scale bar $=2 \mu \mathrm{m}$ ). (C) Mature spore with the exospore $(\boldsymbol{>})$, polaroplast $(\mathrm{P})$, and posterior vacuole $(\mathrm{PV})$. The spore has 12 to 13 coils in the polar filament $(\rightarrow)($ scale bar $=500 \mathrm{~nm})$ 
Sections of extruded polar filaments extending beyond the xenoma boundaries into the host tissue (Fig. 3B) were also observed. Longitudinally sectioned mature spores revealed 12 to 13 coils of polar filament (Fig. 3C). Frequently, host cells were observed containing mature spores, with no evidence of spore degeneration.

\section{Phylogenetic analysis}

The newly obtained sequence of Glugea hertwigi was deposited in GenBank under accession number GQ203287. The length of this sequence is $1856 \mathrm{bp}$. The length of the alignment used for analysis was $1776 \mathrm{bp}$. Phylogenetic analysis clearly demonstrated that G. hertwigi belongs to a group of closely related

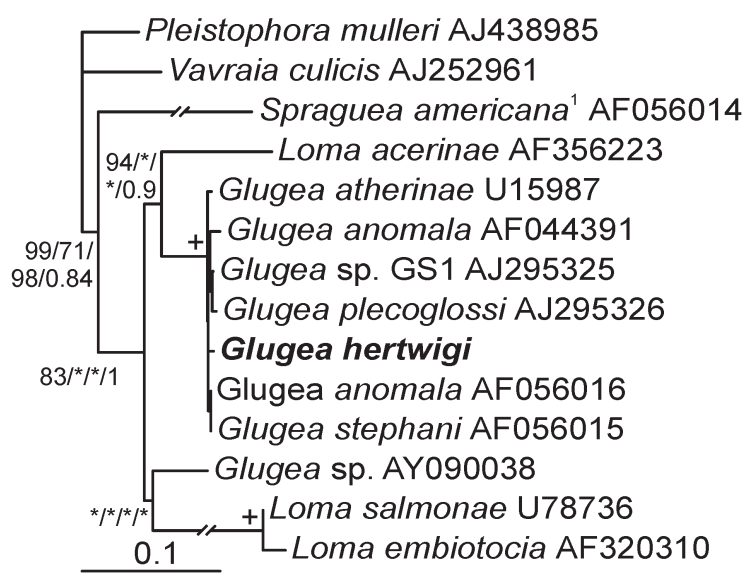

Fig. 4. Maximum likelihood tree of Glugea spp. and related species based on partial small subunit and large subunit rDNA plus internal transcribed spacer. Numbers at the nodes are bootstrap values for maximum likelihood, maximum parsimony, LogDet distance, and Bayesian posterior probabilities (PP), respectively. Nodes supported by all bootstrap values of 99 or greater and a PP of 1.00 marked $(+)$. Bootstrap values $<50$ or PP $<0.50$ denoted $\left({ }^{*}\right)$. The lengths of 2 branches, Spraguea americana $^{1}$ and Loma salmonae and L. embiotocia, were halved. The sequence for species ${ }^{1}$ is deposited under the name G. americanus in GenBank

Table 2. Percent sequence identity of Glugea species based on alignment of the length of 1169 positions. ID: identical

\begin{tabular}{|lccccc|}
\hline Sequence & G. hertwigi & G. anomala & G. anomald $^{\mathrm{b}}$ & G. stephani & G. atherinae \\
\hline G. hertwigi & ID & 99.0 & 99.7 & 99.7 & 99.3 \\
G. anomala $^{\mathrm{a}}$ & 99.0 & ID & 99.3 & 99.3 & 98.7 \\
G. anomala $^{\mathrm{b}}$ & 99.7 & 99.3 & ID & 100 & 99.5 \\
G. stephani & 99.7 & 99.3 & 100 & ID & 99.5 \\
G. atherinae & 99.3 & 98.7 & 99.5 & 99.5 & ID \\
\multicolumn{7}{c}{ a GenBank accession no. AF044391; ${ }^{\mathrm{b}}$ GenBank accession no. AF056016 } \\
\hline
\end{tabular}

Glugea spp. (Fig. 4). The resolution within this group of Glugea spp. was very low, but the bootstrap values supporting the whole clade were all $\geq 99$. In our analysis, 1 sequence (AY090038) assigned to Glugea sp., the origin of which is not quite clear, branched separately from the other Glugea spp. sequences. The sequence deposited in GenBank under the name G. americanus was considered to be Spraguea americana (Freeman et al. 2004). The identity of the sequences calculated for Glugea spp. under study is given in Table 2. The percent identity of $G$. plecoglossi was not included in Table 2 because its sequence was 200 bp shorter than other Glugea spp. When the sequence alignment in all Glugea spp. was adjusted for G. plecoglossi and run with an alignment length of $916 \mathrm{bp}$, then the G. plecoglossi sequence demonstrated $99.1 \%$ identity with G. hertwigi and $>98 \%$ identity with $G$. anomala, G. atherinae, and G. stephani.

\section{DISCUSSION}

Unlike a previous phylogenetic study of microsporidia that also included Glugea spp. (Vossbrinck \& Debrunner-Vossbrinck 2005), the present study took into consideration that $G$. americanus (AF056014) was transferred to the genus Spraguea (Freeman et al. 2004). This approach simplified interpretation of phylogenetic relationships among Glugea spp. sequences. Currently, generic assignment of a microsporidium species whose sequence was deposited under accession number AY090038, remains to be verified. In GenBank, it is listed as belonging to Glugea sp. from yellow grouper Epinephelus awoara (China). Wu et al. (2005) assigned the same sequence (AY090038) to the poorly described species G. epinephelus from the Hong Kong grouper E. akaara. Subsequently, taxonomic and molecular characterization of $G$. epinephelusis was mentioned by Zhang et al. (2005) in a study of immune response of E. akaara against this microsporidium, but no molecular data were given.

The results obtained in the present study demonstrate that the sequence of Glugea hertwigi is very closely related to the sequences of $G$. anomala, $G$. atherinae, G. plecoglossi, and G. stephani. Our results support those of Pomport-Castillon et al. (2000), who hypothesized that $G$. anomala, $G$. stephani, and $G$. atherinae may in fact be only 1 species of the genus Glugea based on sequence homology. Evidence for $G$. hertwigi being the same species as $G$. anomala is also supported by suc- 
cessful experimental infection of sticklebacks with $G$. hertwigi from the smelt Osmerus eperlanus (Weissenberg 1968). Additionally, G. atherinae from the sand smelt Atherina boyeri can cross-infect the flounder Platichthys flesus, suggesting a similarity to G. stephani (Mathieu-Daude et al. 1992). Cross-transmission studies in addition to rDNA comparisons have been used to establish species boundaries for the genus Loma. L. embiotocia and L. salmonae were designated as separate species based on their host specificity to shiner perch Cymatogaster aggregata and salmonids respectively (Kent et al. 1995), despite their close homologies of rDNA sequences showing only $1.2 \%$ difference (Shaw et al. 1997). This suggests that there may be little variation in the rDNA sequences across species within a genus, although that work was based on the comparison of only 334 base pairs. The natural hosts for the various Glugea spp. include G. anomala in sticklebacks Gasterosteus aculeatus, G. stephani in flatfishes such as flounder Pseudopleuronectes americanus, Glugea atherinae in sand smelt A. boyeri and the baitfish Dorosoma cepedianum, and G. hertwigi in smelts (Shaw \& Kent 1999). Although phylogenetic analyses imply that close relatedness of Glugea spp. sequences might be a consequence of the ability of microsporidia to adapt to various hosts (associated with little changes in the genome), data on intragenomic variability, sequences of more genes, and data about cross-transmission are needed to verify this hypothesis.

All of the smelts examined in the present study were sampled during the winter and spring months, when the water temperature was at its coldest. This was done because the winter and spring were the most convenient to capture smelt, since this is the time of year they enter freshwater rivers to spawn. Temperature is a known factor for the development of microsporidia in the host, and low temperatures are known to inhibit their development, especially in the early stage of infection (Beaman et al. 1999, Speare et al. 1999). In the present study, the finding of only mature spores and no other developmental stages in all xenomas examined, including the large and small xenomas, suggested that the parasite was no longer replicating. It is likely that the infections that we observed were xenomas that were over-wintering from the previous summer. Through experimental infections of Glugea hertwigi it was determined that the parasite replicates rapidly at $20^{\circ} \mathrm{C}$ and xenomas with mature spores were present 2 wk post-infection (Scarborough \& Weidner 1979), thus demonstrating that the life cycle of the parasite can be completed within a relatively short time. It is unknown to what degree the spores from overwintered xenomas can autoinfect the host in the following summer. In the present study, the presence of germinating spores and sections of everted polar filaments throughout the host tissue beyond the boundaries of the xenomas suggests that the mature xenomas may cause autoinfection in the host, although no early stages of xenomas were seen in the area. A similar finding was reported in three-spined sticklebacks infected with G. anomala (Dykova \& Lom 1978). Autoinfection has been proposed for other microsporidia, such as Loma sp. in Atlantic cod Gadus morhua (Rodriguez-Tovar et al. 2003) and the Amazonian fish Myrophis platyrhynchus (Matos et al. 2003).

In addition to sequence data, the morphology of Glugea hertwigi appeared similar to other species of Glugea. G. hertwigi xenomas examined in the present study were located predominantly in the submucosa and within the mesentery. The presence of the parasite in the submucosa is similar to findings reported by Scarborough \& Weidner (1979) of G. hertwigi in Osmerus mordax, and also consistent with findings for G. stephani in winter flounder Pseudopleuronectes americanus (Cali et al. 1986). The parasite was not observed in the ovaries, although previous reports demonstrate the ovary as a common site of infection (Chen \& Power 1972, Scarborough \& Weidner 1979). Unfortunately, developmental stages of G. hertwigi could not be described because xenomas contained only mature spores. In mature spores the number of coils in the polar filament is often diagnostic for microsporidian species. In the present study of G. hertwigi the polar filament had 12 to 13 coils. This is relatively consistent with those described for $G$. anomala, which are reported to range between 12 and 14 coils, although 11 to 16 coils and 11 to 14 coils were observed in a microsporidian resembling $G$. anomala found in the respective killifish Nothobranchius korthausae and Fundulopanchax filamentosus (Lom et al. 1995). Based on electron micrographs by Takvorian \& Cali (1996), G. stephani contained approximately 12 coils of the polar filament, and $G$. atheriane has been reported to have $>10$ coils of polar filament, although a range was not reported (Berrebi 1979). G. americanus, which had been transferred to the genus Spraguea, had 6 to 8 coils of polar filament (Keohane et al. 1996), thus out of the range of Glugea spp.

Rainbow smelt infected with Glugea hertwigi in PEI demonstrated $24 \%$ prevalence in the present study. This is very similar to what has been reported in the Great Bay region in New Hampshire, with 23.3\% prevalence in Osmerus mordax sampled from October 1951 to April 1952 (Haley 1954). A previous report suggested that females were more susceptible to infection and carried heavier loads of $G$. hertwigi cysts than males (Chen \& Power 1972). In the present study the infection rates were marginally higher in females $(26 \%)$ than in males $(23 \%)$ and the infection intensity 
was similar in the 2 sexes, thus indicating that sex was not a factor for infection. This may be explained by the fact that the parasite was not found in ovaries in the present study, while others report the ovary as a common site of infection. The affinity of the parasite to ovarian tissue is unknown and it may vary depending on host, parasite, or environmental factors. It is likely that parasites with an affinity for ovarian tissue would result in heavier and more frequent infections in female fish. It is possible that our sampling in the winter and spring gave underestimates of the parasite prevalence because the parasite likely most actively replicates in the summer when temperatures are at their highest. Considering the 2 wk life cycle of the parasite, which was demonstrated in a laboratory infection at $20^{\circ} \mathrm{C}$ by Scarborough \& Weidner (1979), xenomas may develop and degrade within a single summer. Histological examination demonstrated the presence of remnant granulomas within the mesentery, which were suggestive of previously degraded xenomas and other xenomas with a heavy inflammatory infiltrate. The persistence of $G$. hertwigi xenomas in PEI smelt, however, is unknown and is most likely related to environmental factors such as temperature. Xenoma size has been used as a predictor for age of the xenomas (Rodriguez-Tovar et al. 2004) and in the present study the finding of large, small, and degraded xenomas within an individual may reflect that infection can occur continuously as opposed to a single infection time. We have demonstrated that the parasite over-winters but does not seem to actively replicate in fish through the winter, but other infection dynamics in PEI smelt are yet to be determined. Investigating the total amount of time that xenomas may persist and the origins of infections, whether in freshwater or saltwater, would be helpful in better understanding Glugea spp. infections in PEI fish.

Acknowledgments. The authors gratefully thank D. Wadowska for her help in preparing samples for TEM and N. Lewis for assistance in sampling and dissecting fish. Financial support was provided by research projects of the Institute of Parasitology, Biology Centre of the Academy of Sciences of the Czech Republic (Z60220518 and LC522), and a Natural Sciences and Engineering Research Council of Canada Strategic Grant.

\section{LITERATURE CITED}

Beaman HJ, Speare DJ, Brimacombe M (1999) Regulatory effects of water temperature on Loma salmonae (Microspora) development in rainbow trout. J Aquat Anim Health 11:237-245

Berrebi P (1979) Etude ultrastructurale de Glugea atherinae n. sp., microsporidie parasite de l'athérine Atherina boyeri Risso 1810 (poisson téléostéen) dans les lagunes du Languedoc et de Provence. Z Parasitenkd 60:105-122
Cali A, Takvorian PM, Ziskowski JJ, Sawyer TK (1986) Experimental infection of American winter flounder (Pseudopleuronectes americanus) with Glugea stephani (Microsporida). J Fish Biol 28:199-206

Canning EU, Lom J (1986) The microsporidia of vertebrates. Academic Press, London

Chen M, Power G (1972) Infection of American smelt in Lake Ontario and Lake Erie with the microsporidian parasite Glugea hertwigi. Can J Zool 50:1183-1188

Delisle CE (1972) Monthly variations of Glugea hertwigi (Sporozoa: Microsporidia) in different tissues and organs of the freshwater smelt and the consequences of this infection on the annual massive mortality of this fish. Can J Zool 50:1589-1600

Dykova I, Lom J (1978) Tissue reaction of the three-spined stickleback Gasterosteus aculeatus L. to infection with Glugea anomala (Moniez, 1887). J Fish Dis 1:83-90

Freeman MA, Yokoyama H, Ogawa K (2004) A microsporidian parasite of the genus Spraguea in the nervous tissues of the Japanese anglerfish Lophius litulon. Folia Parasitol (Praha) 51:167-176

Haley JA (1954) Microsporidian parasite, Glugea hertwigi in American smelt from the Great Bay region, New Hampshire. Trans Am Fish Soc 83:84-90

Hall TA (1999) Bioedit: a user-friendly biological sequence alignment editor and analysis program for Windows 95/98/NT. Nucleic Acids Symp Ser 41:95-98

Ieshko EP, Evseeva NV, Sterligova OP (2000) The role of fish parasite in fresh-water ecosystems exemplified by a parasite of the smelt (Osmerus eperlanus). Parazitologiia 34:118-124

Kent ML, Dawe SC, Speare DJ (1995) Transmission of Loma salmonae (Microsporea) to Chinook salmon in seawater. Can Vet J 36:98-101

Keohane EM, Takvorian PM, Cali A, Tanowitz HB, Wittner M, Weiss LM (1996) Identification of a microsporidian polar tube protein reactive monoclonal antibody. J Eukaryot Microbiol 43:26-31

> Larkin MA, Blackshields G, Brown NP, Chenna R and others (2007) Clustal W and Clustal X version 2.0. Bioinformatics 23:2947-2948

> Lom J, Noga EJ, Dykova I (1995) Ocurrence of a microsporean with characteristics of Glugea anomala in ornamental fish of the family Cyprinodontidae. Dis Aquat Org 21:239-242

Mathieu-Daude F, Faye N, Coste F, Manier F, Marques A, Bouix G (1992) Occurrence of microsporidiosis in marine cultured gilt-head sea bream from the Languedoc coast: a problem of specificity in the genus Glugea (Protozoa, Microspora). Bull Eur Assoc Fish Pathol 12:67-70

Matos E, Corral L, Azevedo C (2003) Ultrastructural details of the xenoma of Loma myrophis (Phylum Microsporidia) and extrusion of the polar tube during autoinfection. Dis Aquat Org 54:203-207

> Nepszy SJ, Budd J, Dechtiar AO (1978) Mortality of young-ofthe-year rainbow smelt (Osmerus mordax) in Lake Erie associated with the occurrence of Glugea hertwigi. J Wildl Dis 14:233-239

> Pomport-Castillon C, DeJonckheere JF, Romestand B (2000) Ribosomal DNA sequences of Glugea anomala, $G$. stephani, G. americanus and Spraguea lophii (Microsporidia): phylogenetic reconstruction. Dis Aquat Org 40: 125-129

> Rodriguez-Tovar LE, Wadowska DW, Wright GM, Groman DB, Speare DJ, Whelan DS (2003) Ultrastructural evidence of autoinfection in the gills of Atlantic cod Gadus morhua infected with Loma sp. (phylum Microsporidia). Dis Aquat Org 57:227-230 
Rodriguez-Tovar LE, Speare DJ, Markham RJF, Daley J (2004) Predictive modelling of post-onset xenoma growth during microsporidial gill disease (Loma salmonae) of salmonids. J Comp Pathol 131:330-333

Ronquist F, Huelsenbeck JP (2003) MrBayes 3: Bayesian phylogenetic inference under mixed models. Bioinformatics 19:1572-1574

Scarborough A, Weidner E (1979) Field and laboratory studies of Glugea hertwigi (Microsporidia) in the rainbow smelt Osmerus mordax. Biol Bull (Woods Hole) 157:334-343

Shaw RW, Kent ML (1999) Fish microsporidia. In: Whitner M, Weiss LM (eds) The microsporidia and microsporidiosis. ASM Press, Washington, DC, p 418-446

Shaw RW, Kent ML, Docker MF, Brown AMV, Devlin RH, Adamson ML (1997) A new species of Loma (Microsporea) in shiner perch (Cymatogaster aggregata). J Parasitol 83: 296-301

Speare DJ, Beaman HJ, Daley J (1999) Effect of water temperature manipulation on a thermal unit predictive model for Loma salmonae. J Fish Dis 22:277-283

Stamatakis A (2006) RAxML-VI-HPC: maximum likelihoodbased phylogenetic analyses with thousands of taxa and mixed models. Bioinformatics 22:2688-2690

Swofford DL (2001) PAUP: phylogenetic analysis using parsimony, Version 4.0b10. Sinauer Associates, Sunderland, MA

Takvorian PM, Cali A (1996) Polar tube formation and nucle-

Editorial responsibility: Dieter Steinhagen,

Hannover, Germany oside diphosphatase activity in the microsporidian, Glugea stephani. J Eukaryot Microbiol 43:102S-103S

Vossbrinck CR, Debrunner-Vossbrinck BA (2005) Molecular phylogeny of the Microsporidia: ecological, ultrastructural and taxonomic considerations. Folia Parasitol (Praha) 52: 131-142

Vossbrinck CR, Baker MD, Didier ES, Debrunner-Vossbrinck BA, Shadduck JA (1993) Ribosomal DNA sequences of Encephalitozoon hellem and Encephalitozoon cuniculi: species identification and phylogenetic construction. J Eukaryot Microbiol 40:354-362

Vossbrinck CR, Andreadis TG, Vávra J, Becnel JJ (2004) Molecular phylogeny and evolution of mosquito parasitic Microsporidia (Microsporidia: Amblyosporidae). J Eukaryot Microbiol 51:88-95

Weissenberg R (1968) Intracellular development of the microsporidian Glugea anomala Moniez in hypertrophying migratory cells of the fish Gasterosteus aculeatus, an example of the formation of the xenoma tumors. J Protozool 15:44-57

Wu HB, Wu YS, Wu ZH (2005) Occurrence of a new microsporidium in the abdominal cavity of Epinephelus akaara. Acta Hydrobiol Sin 29:150-154

Zhang JY, Wu YS, Wu HB, Wang JG, Li AH, Li M (2005) Humoral immune responses of the grouper Epinephelus akaara against the microsporidium Glugea epinephelusis. Dis Aquat Org 64:121-126

Submitted: June 2, 2009; Accepted: August 20, 2009

Proofs received from author(s): November 9, 2009 